\title{
BIOLOGICAL CHANGES OCCURED IN SOYBEAN SEED DURING EXPOSING TO SEVERAL TYPES OF SEED PRIMING
}

\author{
[135] \\ Mohamed $^{1}$ H.M., Zaki ${ }^{1}$ A.M., Olfat H. El-Bagoury ${ }^{1}$ and Rania A.A. Younis ${ }^{2}$ \\ 1- Agronomy Dept., Fac. of Agric., Ain Shams Univ.., P.O. Box 68 Hadayk Shoubra, 11241, \\ Cairo, Egypt \\ 2- Genetic Dept. Fac. of Agric., Ain Shams Univ., P.O. Box 68 Hadayk Shoubra, 11241, Cairo, \\ Egypt
}

Keywords: Soybean, Glycine max, Osmo-priming, Salt-priming, Hydration, Enzyme activity, Peroxidase, Esterase

\section{ABSTRACT}

Biological experiments were carried out at Agronomy Seed Lab., Agronomy Dept., Faculty of Agriculture, Ain Shams University and Ain Shams Center For Genetic Engineering and Biotechnology ACGEB, Genetic Dept., Faculty of Agriculture, Ain Shams University during 2016/2017 season. Priming and its duration were investigated whereas different types of priming (hydro-priming, osmopriming and salt-priming) and different periods of each type (short- medium and long periods) were stuied. Newly harvested soybean seeds cultivar (Giza 111) were submitted from Field Crop Institute, Agricultural Research Center (ARC). It was found that type of priming enhanced germination percentage significantly from low performance of $40 \%$ to $51 \%, 68 \%$ and $75.5 \%$ for hydration, osmopriming and salt priming respectively. Extending exposing period to the longest period gave significantly maximum increment in seed germination Maximum germination enhancement was achieved when calcium chloride solution was used for the longest period (48 hrs.) giving value of $96.0 \%$. Such increment reached $140 \%$ as compared with control. It was noticeable that increasing soaking period to the longest period examined in this investigation accelerated the rate of germination to a maximum level. Salt priming produced longest soybean seedling shoot when compared with control. Overall, for most results obtained in this trial, seed primed with $\mathrm{CaCl}_{2}$ showed better perfor- mance than those primed with water or PEG solution. Seedling dry weight revealed a significant effect in a similar manner of seedling length. The longest exposing priming period showed a significant effect on seedling dry weight. Soybeans seeds proteins exposed to priming for all three periods used in this investigation varied from control, whereas number of protein bands on SDS gel increased from 10 bands separated on control pattern to 13,11 and 12 for hydration treatment at periods of 6,12 and 24 hrs., respectively. Also number of mono poly-uni. and unique bands varied as well as its intensive dye which reflect that amount of protein formed varied between treatments. Considering exposing seeds to salt solution of $\mathrm{CaCl}_{2}$ for longest period ( $48 \mathrm{hrs}$.) less bands of separated protein were formed on SDS gel. Biological seed quality was assessed by extracting proteins on native polyacrylamide gel electrophoresis, whereas, all priming treatment at application periods caused on increasing in peroxidase activity compared to control (untreated seeds). It was remarkably that the longest period of expose showed the highest peroxidase activity when compare to control and also for the short and medium exposing periods ( 6 and $12 \mathrm{hrs}$.). Also it was noticed that there were a unique diffuse band at the end of the lane, these bands were less intensive in staining color, meaning that their activities is less than those extracted from hydro-primed seeds for short and medium periods ( 6 and 12 hrs. respectively). Seed esterase activity bands had two prolonged regions, these bands appeared as a diffuse bands. Esterase activity bands of PAGE gel showed less activity as subjected to all priming types at any period used in this investigation (long, medium and 
short) when compared to untreated seed (control). It was clear that increasing period of exposing seeds to priming reduced esterase activity since the intensive band diminished in their intensive color.

\section{INTRODUCTION}

Soybean (Glycine Max L., Merrill) is one of the most important protein and oil crop providing both man and animals with nutrients. Moreover soybean has numerous uses of its products. To enhance production of soybean seed yield, farmers consider having good crop establishment, proper plant tillage and adequate amount of fertilizer. Therefore poor germination due to low seed viability is a serious problem limiting the productivity of soybean. Germination and field emergence are important issues in plant production and they have significant effect on the next stages of plant growth in field. Seed priming is a pre-germination treatment in which seeds are held at water potential that allows imbibition, but prevents radical extension. Seed priming has been used to treat seeds in an attempt to improve germination and seedling establishment. Priming stimulates physiological and biochemical activities occurred within seed such seed treatment can have improved germination rate and uniformity, particularly under adverse conditions. The observed improvements were attributed to priming-induced quantitative changes in biological activities including greater amylase activity, increasing free sugar and DNA during seed germination (Sung \& Chang 1993).

Priming effects DNA and RNA synthesis, Alpha-amylase activities and cause better embryo growth. Additionally, Sayed et al (2014) pointed out that seedling weight, main stem weight, lateral stem weight and germination percentage indicated a significant improvement at 1 percent level for hydro priming of soybean seeds. However, Chavan et al (2014) reported that all types of priming enhanced field emergence of soybean seeds. It was found that the hydration treatment significantly reduced time to $50 \%$ of germination from $51 \mathrm{hrs}$. to 30 hrs., similarly, time to $30 \%$ of seedling emergence was reduced by $18 \%$. Nevertheless, incomplete hydration, which permits some metabolic activity and repair mechanism, is the base for the seed pretreatment known as priming resulting in an acceleration and more uniform germination especially in unfavorable conditions such as drought. Some researchers found that hydro priming did not affect germination under stress (Toselli and
Lasenve, 2003). Improvement in yield could happen in two ways i.e. by a adopting the existing verities to grow better in their environment or by altering the relating proportion of different plant parts so as to increase the yield of economically important parts. The influence of seed priming signification increased the seed yield. The statistically analyzed results showed that seed hydro priming treatments significantly influenced numbers of pods per hectare (Chavan et al 2014). Priming consists of a regulated hydration, in water or osmatic solutions that permits the improvement of some metabolic process but prevents germination. Advantages obtained during priming are retained after seed dehydration. Hossien et al (2011) studied the effect of osmo-priming of PEG 6000 solution (priming media) on germination behavior and vigor of soybean seeds. Results made clear that different osmatic potential and priming duration had significant effect on germination percentage, mean germination time, germination index, and time to get $50 \%$ germination. It was found that $-1.2 \mathrm{MPa}$ osmotic potential increased germination percentage, germination index and seed vigor, meanwhile, decreased mean germination rate, time to get $50 \%$ germination. Additionally, it was observed that 12 h. priming duration had most effect on studied traits. Later Muhammad et al (2014) conducted a study to determine the effect of osmo- priming on phenology and yield of soybean seed, they applied three priming duration (6,12 and $18 \mathrm{hrs}$.) and five different concentration of PEG 8000 solution (0.2, $1.1,-1.8,-3.0$ and $-4.2 \mathrm{MPa})$. They reported that average over all treatment priming for $6 \mathrm{hrs}$. with 1.8 or $-1.1 \mathrm{MPa}$ were the most beneficial treatments. Similarly, Muhammad et al (2010) indicated that germination traits values decreased with increase in seed priming duration, while relative growth rate (RGR) increased with increase in seed priming duration. They reported that absolute growth rate (AGR) and crop growth rate (CGR) enhanced with increase in PEG concentration from 0.0 to $300 \mathrm{~g}$ PEG 8000 per L water. Likewise, seed priming not only affect germination traits and emergency, but also positively affect growth and yield. Muhammad et al (2008) pointed out that osmo-priming at osmotic potential of $-1.1 \mathrm{MPa}$ increase emergence per unit area and results in higher seed yield of soybean. Also treatment duration of $6 \mathrm{hrs}$. caused uniformly emergence and consequently increased seed yield. Simple priming techniques using salt solutions gave way to elaborate and sophisticated media that warrant close monitoring. Moreover, Mohammadi

(2009) 
showed that seed priming significantly improved soybean plant traits, in both field and laboratorial studies. Seed primed with potassium nitrate showed the highest values for all of the evaluated traits, it increased germination percentage(GP), germination rate (GR), seedling dry weight (SDW), plant high, leaf area index (LAI) as compared to control. There were no significant differences between this treatment and the seeds primed with ammonium nitrate for all of the traits under study. When Mewael et al (2010) subjected soybean seed to different types of priming including $\mathrm{KCl}$ (100ppm), $\mathrm{CaCl}_{2} .2 \mathrm{H}_{2} \mathrm{O}$ (0.5\%) and $\mathrm{KH}_{2} \mathrm{Po}_{4}(50$ ppm) using high soybean seed quality and low soybean quality as well, their results revealed that, irrespective of seed quality, speed of germination showed significant difference due to seed priming treatments, seed primed with GA3 (20ppm) recorded significantly higher speed of germination followed by $\mathrm{CaCl}_{2}$. $2 \mathrm{H}_{2} \mathrm{O} \quad(0.5 \%)$. Meanwhile Chavan et al (2014) stated that priming soybean seeds with $\mathrm{CaCl}_{2}$. $2 \mathrm{H}_{2} \mathrm{O}(0.5 \%)$ were superior in plant height, number of branches, number of pods per plant, number of seeds per pod, seed yield per hectare over non-primed seeds. Proteomic analysis in Arabidopsis revealed that new proteins are involved either in imbibition process of seeds or in the seed dehydration process, which helps to characterize seed vigor of commercial seed lots and to developed and monitor priming treatments. Activities of several enzyme associated with the germination process have been observed to change in response to seed priming.

\section{MATERIALS AND METHODS}

Biological experiments were carried out at Seed Lab. Agronomy, Dept., Faculty of Agriculture, Ain Shams University and Center For Genetic Engineering and Biotechnology, Genetic Dept., Faculty of Agriculture - Ain Shams University during the period 2016/2017 seasons.

\section{Seed material}

Newly harvested soybean seeds of cultivar (Giza 111) were submitted from Field Crop Institute, Agricultural Research Center (ARC). Seed moisture content was (10\%). Fresh seed was subjected to treatments to evaluate biological treats while protein extracts were kept in deep freezer at $20{ }^{\circ} \mathrm{C}$ for enzyme activity assay and protein pattern analysis.

\section{Treatments studied}

Soybean seed cultivar (Giza 111) was subjected to three different types of seed priming:

1-Hydro-priming, 2-Osmo-priming and 3-Saltpriming

Meanwhile, three different periods of exposing to each priming type were studied.

1-Short period were $6 \mathrm{hrs}$. for hydro-priming, 12 hrs. for osmo-priming and 12 hrs. for saltpriming.)

2-Medium period were (12 hrs for hydropriming, 24 hrs. for osmo-priming and $24 \mathrm{hrs}$. for salt-priming.)

3-Long period were (24 hrs. for hydro-priming, $48 \mathrm{hrs}$. for osmo-priming and $48 \mathrm{hrs}$. for saltpriming.)

\section{Hydro-priming}

Hydro-priming treatments were carried out for three different periods by placing soybean seeds $(100 \mathrm{~g})$. Between towel papers and sprayed with enough distilled water to keep seed wet during the period of hydration treatment. Seed were dried to their initial moisture content (10\%) under laboratory conditions for each treatment $\left(60 \% \mathrm{RH}\right.$. and $\left.28{ }^{\circ} \mathrm{C}\right)$ until priming treatments were fulfilled.

\section{Osmo-priming}

Priming is a treatment based on incomplete seed hydration, therefore, Osmo solution of poly ethylene glycol (PEG 6000) with water potentials of $-0.8 \mathrm{MPa}$ for Osmo-priming. Soybean seeds were kept in a beaker contained 300 mls of (PEG 6000) solution and kept at room temperature for three different periods $(12,24$ and $48 \mathrm{hrs}$.). Six replications were performed for each period. Seeds were dried by placing on filter paper at room temperature $\left(60 \% \mathrm{RH}\right.$ and $\left.28{ }^{\circ} \mathrm{C}\right)$ until reached the original moisture content $(10 \%)$.

\section{Salt-priming}

Salt solution was prepared by dissolving $21.2 \mathrm{~g}$ calcium chloride $\left(\mathrm{CaCl}_{2}\right)$ per $1000 \mathrm{~cm}^{3}$ of distilled water $(2.12 \%)$. This solution was used for soybean seed priming by soaking (100 g) seeds in 1 liter. of $2.12 \%$ salt solution. Such procedure was repeated three times to obtained seed treated with different periods of exposing. Treated seeds were re-dried to initial moisture content (10\%) by placing seeds on filter paper at room temperature $(60 \% \mathrm{RH}$ and $\left.28^{0} \mathrm{C}\right)$. 


\section{Data Recorded}

\section{Germination}

The germination test was carried out according to the procedure described of "International Rules for Seed Testing" published by (International Seed Testing Association- ISTA, 1996). Six replications of 100 seeds each were planted in pots contained sterilized sand. The seed were spaced uniformly and adequately apart on the sand, the germination test was performed at temperature of $25^{\circ} \mathrm{C}$ and the following parameters were recorded:

\section{1- Germination percentage (G \%)}

$$
\mathrm{G} \%=(\mathrm{t} / \mathrm{T})^{*} 100
$$

Where $(t)$ is the number of seed germinated and $(T)$ is the number of seeds used in germination test.

\section{2- Germination rate (GR)}

Germination rate was calculated as described by (International Seed Testing AssociationISTA, 1996) as the following formula.

$$
G R=\frac{A+B+C+D+\cdots .+N}{n(A+B+C+D+. .+N)}
$$

Where: $A=$ number of germinated seeds at $1^{\text {st }}$ count.

$\mathrm{B}=$ number of germinated seeds at $2^{\text {nd }}$ count.

$\mathrm{C}=$ number of germinated seeds at $3^{\text {rd }}$ count.

$D=$ number of germinated seeds at $4^{\text {th }}$ count.

$\mathrm{N}=$ number of germinated seeds at final count.

$\mathrm{n}=$ number of counts.

\section{3- First day of germination (FDG)}

Day on which the first germination occurred.

\section{4- Last day of germination (LDG)}

Day on which the last germination occurred.

\section{5- Germination period (GP)}

Period (days) between the first and the last germination occurred in germination process.

\section{6- Shoot length (cm)}

Shoot length was measured from the point of its beginning to its final length.

\section{7- Root length (cm)}

Root length was measured from the point of its beginning to its final length.

\section{8- Seedling length (cm)}

Seedling length was measured from the point of its beginning to its final length.

\section{9- Seedling dry weight (g)}

Seedlings were dried at $70^{\circ} \mathrm{C}$ for $24 \mathrm{hrs}$. in oven and weighted in (g.)

\section{Protein pattern}

Quantities of each chemical for pour resolving

\begin{tabular}{|c|c|c|}
\hline Reagent & $\begin{array}{c}\text { Resolving } \\
\text { gel }\end{array}$ & $\begin{array}{l}\text { Stacking } \\
\text { gel }\end{array}$ \\
\hline Deionized water & $3.5 \mathrm{~mL}$ & $2.1 \mathrm{~mL}$ \\
\hline $\begin{array}{l}30 \% \text { acrylamide: bisacrylamide } \\
(29: 1)\end{array}$ & $4.0 \mathrm{~mL}$ & $0.63 \mathrm{~mL}$ \\
\hline $1.5 \mathrm{M}$ Tris-HCl, $0.4 \%$ SDS, $\mathrm{pH} 8.8$ & $2.5 \mathrm{~mL}$ & ------ \\
\hline $0.5 \mathrm{M}$ Tris- $\mathrm{HCl}, 0.4 \% \mathrm{SDS}, \mathrm{pH} 6.8$ & ------ & $1.0 \mathrm{~mL}$ \\
\hline $\begin{array}{l}10 \% \text { ammonium persulfate (cata- } \\
\text { lyst) }\end{array}$ & $100 \mu \mathrm{L}$ & $30 \mu \mathrm{L}$ \\
\hline TEMED (catalyst) & $10 \mu \mathrm{L}$ & $7.5 \mu \mathrm{L}$ \\
\hline
\end{tabular}
and stacking gels were as follow:

\section{Gel staining}

Gel was removed from the tank carefully, and two plates were taken apart by a spatula. Gel was placed in a small plastic tray and labeled for initials on a piece of tape. Place the gel and tray on a rocking platform. Gel was shaked $\sim 2$ minutes. water was drained from the gel and enough Commassie Blue buffer was added to cover the gel, while allowing the gel to move freely when the tray is rocked. Gel container was covered with saranwrap and was rocked overnight. Make sure that the gel does not stick to the bottom of the tray. In the morning, the stain buffer was drained. Distain the gel by filling the container about half full with deionized water. Gel was shaked in the water for $\sim 2$ minutes. Pour off the water and add new deionized water. Repeat,( if necessary), until protein bands become visible. When individual bands were detectable, data were recorded. Gel photographed against a white background. 


\section{Enzyme Activity Test \\ Extraction of isozymes}

Soybean seeds were ground at a weight of $(0.5 \mathrm{~g})$ in a motor and pestle using liquid nitrogen with extraction buffer of $100 \mathrm{mls}$ of IM sucrose, $0.056 \mathrm{M}$ mercaptoethanol and $2 \mathrm{~m}$ tris $-\mathrm{HCl}(\mathrm{pH}$ 7.5). Each sample was vortexed for $15 \mathrm{sec}$. and centrifuged for $10 \mathrm{~min}$. at $10,000 \mathrm{rpm}$ at $-50^{\circ} \mathrm{C}$. The supernatant was divided and transferred to $1 \mathrm{ml}$ eppendorof tubes and kept in deep freezer ($80^{\circ} \mathrm{C}$ ) until use for electrophoretic analysis according to (Koller and Kalatlukudy, 1982).

\section{Gel Preparation}

The separation gel was prepared as polyacrylamide standard gel (8\%) with adjusting $\mathrm{pH}$ at $8.6(25 \mathrm{ml}$ acrylamide $30 \%, 75 \mathrm{ml}$ Gel buffer, $30 \mathrm{mg}$ Sodium sulfite, $4 \mathrm{ml}$ Ammonium peroxide sulphate and $100 \mathrm{ul}$ TEMED). Gel was poured on the plate and 10 -well comb was placed immediately. Gel polymerized about 30 mins.

\section{Sample Application}

A volume of 50 uls. of extract of each sample was mixed with 10 uls. Bromophenol blue, this mixture was applied to each.

\section{Electrophoresis Condition}

The gel was completely covered with electrode buffer which connected to power supply voltage at $200 \mathrm{~V}$ for $2 \mathrm{hrs}$.

\section{Enzymes assay}

\section{1- Peroxidase}

Polyacrylamide gels were detected the presence of enzyme activity using (12.5 w/v, polyacrylamide) as described in the manufacturer's manual (Pharmacia; Phast System-unit). Prior to electrophoresis, samples were mixed with sample buffer. Immediately after electrophoresis, the gels were incubated with substrates. These included the following: -3,4-dihydroxyphenyl alanine ( $L$ DOPA) ; caffeic acid; homoprotocatechuic acid; 2,4-DCP; $N, N, N^{\prime}, N^{\prime}$ - tetra met hyl-pphenylene diamine containing $0.05 \mathrm{M} 4$-aminoantipyrine.

Gels were flooded with a $10 \mathrm{mM}$ solution of substrate plus $50 \mathrm{mM} \mathrm{H}_{2} \mathrm{O}_{2}$ in $0.1 \mathrm{M}$ potassium phosphate buffer $(\mathrm{pH} 7.0)$ at room temperature.
The gels were developed with 3, 3'diaminobenzidine, o-dianisidine, ABTS and 4chloro-1-naphthol containing $1 \mathrm{ml}$ substrate solution mixed with $1 \mathrm{ml} 30 \mathrm{Mm} \mathrm{H}_{2} \mathrm{O}_{2}$ and $8 \mathrm{ml} 0.1 \mathrm{M}$ sodium phosphate buffer $(\mathrm{pH}$ 6.0). When the stained peroxidase bands appeared on the gels, and were photographed immediately.

\section{2-Esterase}

The gels were stained after electrophoresis, and incubated at $37^{\circ} \mathrm{C}$ in dark until complete staining after adding the appropriate substrate in staining solution, according (Koller and Kolattukudy, 1982).

$\begin{array}{ll}100 \mathrm{Mm} \mathrm{Na} \text {-phosphate, } \mathrm{PH} 6.0 & 50 \mathrm{ml} \\ \text { a-naphthyl acetate } & 25 \mathrm{ml} \\ \text { Fast blue RR salt } & 50 \mathrm{ml}\end{array}$

\section{Gel fixation}

After the appearance of the enzyme bands, reaction stopped by washing the gel two to three times with tap water. and by adding the fixing solution which consists of 9 parts of ethanol and 11 parts of $20 \%$ glacial acetic acid. The gel was kept in fixing solution for $24 \mathrm{~h}$ and rinsed with tap water two times, then photographed. Gels were applied to a scanning densitometer interfaced with a computer for a quantitation to quantitate the changes in translation products as affected by enzyme activity as well as aging.

\section{Statistical analysis}

The complete randomized design was applied with 4 replicates. The obtained data were exposed to proper statistical analysis according to Snedecor and Cochran (1991). The least significant difference at 0.05 and level of significance were calculated for means comparisons.

\section{RESULTS AND DISCUSSION}

\section{Germination and seedling characteristics}

Different types of priming at different exposing periods were examined to clarify the effect of both factors on soybean seed performance during germination and seedling characteristics (Table 1). Germination percentage affected significantly by types of priming, exposing time and their interaction. Type of priming significantly enhanced germi- 
nation percentage from low performance of $40 \%$ to $51 \%, 68 \%$ and $75 \%$ for hydro-priming, osmopriming and salt priming respectively. The maximum value( $75.5 \%$ ), was recorded for soybean seed exposed to salt priming, such increment in germination percentage reached $88.75 \%$ as compared with control, meaning that salt-priming had the superiority over other types ( hydro-priming and osmo-priming).

Obtained results showed that exposing period extended to the longest period which gave the maximum increment in seed germination, (78.7\%). Priming duration generally accelerated germination percentage and scored the greatest enhancement when extending exposing period to the longest period. The improvement in primed seed might be due to the completion of pre-germinative metabolic activities which makes seed ready for radicle protrusion so the seed becomes more rapidly for germination.

Interaction between priming type and duration showed significant effects on germination percentage, whereas, maximum germination was achieved when calcium chloride solution was used for the longest period (48 hrs.) giving value of $96.0 \%$ and that increment reached $140 \%$ as compared with control (Table 1). Priming improved germination throughout seed treatment, and that may be due to the metabolic repair process which buildup metabolites or osmotic adjustments during priming or improve membrane integrity which enhanced physiological activities at germination (Park et al 1999 and Mohammadi et al 2009).

In the same manner, germination rate revealed that types of priming and salt-priming enhanced germination rate giving maximum values as compared to other types of priming (hydropriming and osmo-priming) as shown in (Table 1).

Types of priming significantly accelerated germination significantly when compared to control. Irrespective of seed quality, seed germination showed significant differences when application period was considered. The longest period gave maximum rate of germination $(0.60)$ as compared to other periods (short and medium periods) (Table 1).

Maximum germination speed was resulted when soybean soaked in $2.12 \% \mathrm{CaCl}_{2}$ solution for the longest period (48 hrs.) scored 0.64. Such germination rate was raised by $39.13 \%$ when compared to control (0.46). Exposing seed to the longest period of priming gave a chance to physiological process to break down food reserved in cotyledons, activation enzymes and repair mechanisms.

Data obtained in (Table 1) revealed that there was un-significant difference between FDG, LDG and GP when priming type, application period and their interaction were considered except when priming types for FDG and GP for priming type (Table 1). Hydro-priming and osmo-priming significantly delay the FDG from 7 days (control) to 7-8 and 7-5 days treatments respectively. Seed soaked in $\mathrm{CaCl}_{2}$ solution for salt-priming did not show significant differences compared to control. The observed improvements in emergence of primed seed may be attributed to priming that induces quantitative changes of biochemical content of the soybean seed and improvement in membrane integrity and enhance physiological activities at germination stages. Such improvement in emergence of primed seeds may be due to the fact that priming induces a range of biochemical changes in the seed which required to germination process, i.e. breaking dormancy, hydrolysis of inhibitors, imbibition and enzyme activation (Ajouri et al 2004).

\section{2-.Seedling Characteristics}

Shoot length of soybean seedling varied significantly due to type of priming, where salt priming produced longest shoot $(3.5 \mathrm{~cm})$ as compared with control $(2.7 \mathrm{~cm})$ and other types of priming (3.1 and $3.2 \mathrm{~cm}$ ) for hydration and osmo-priming respectively (Table 2). Primed seed with $\mathrm{CaCl}_{2}$ showed better performance than those primed with water. Final shoot length was of salt priming suggests nontoxicity of $\mathrm{CaCl}_{2}$. On the other hand, longest period gave maximum shoot length (3.6 $\mathrm{cm}$ ) when compared to the other two periods (short and medium periods), this values reached significance in (Table 2). Interaction between priming type and applied period showed significant differences, whereas, salt priming for the longest application produced the tallest shoot length $(4.0 \mathrm{~cm})$. This can be attributed to more salt accumulation in seed enhancing seedling growth.

Root length of seedling subjected to applied treatments showed the same attitude for shoot length. Seedling subjected to salt priming gave longest root length $(4.3 \mathrm{~cm})$ as compared to other types of priming (Table 2), such superiority was highly significant. The longest applied period gave the maximum root length $(4.4 \mathrm{~cm})$, Period of priming to maximum period may allow more time to beneficial change within seed that enhance seed- 

types of seed priming

ling growth. In fact, improved seed performance induced by seed priming may be due to altered physiological condition of the embryo. It may be also due to liberation of enzymes, thus rapidly increasing production of soluble food nutrients which push whole system in motion. Seedling subjected to salt priming for the longest period produced longest root $(5.0 \mathrm{~cm})$, while interaction between type of priming and period of application significantly differences (Table 2 ).

Seedling length had similar results of root and shoot length. Salt-priming significantly produced tallest seedling $(7.8 \mathrm{~cm})$ as compared to other two types of priming (Table 2). Increment in seedling length of seeding salt priming reached $25.81 \%$ more than control seedling. Mechanism by seed priming improves germination performance have been discussed by several workers. Seeds complete first phase of germination (imbibition phase), whereas phase II of biological and physiological changes take place. Many nutrients within seed become in suitable form for germination. The longest period of exposing soybean seed to priming significantly increase seedling length reaching (8.0 $\mathrm{cm}$ ). Interaction between type of priming and applied period revealed significant differences of seedling length, whereas, maximum seedling length $(9.0 \mathrm{~cm})$ was recorded for seedling produced from seed salt-priming at longest exposing period (Table 2).

Dry matter synthesized in seedling is an important factor for having a vigorous and healthy seedling, such seedling is a start to have a vigorous plant which in turn in more dry matter and increase yield. Data of seedling dry weight revealed a significant effect of priming type turn in, whereas, same attitude of seedling length was detected in dry weight.

Commonly, hydro-priming, osmo-priming and salt priming enhanced germination and seedling characteristics. It seems that longest periods used in this investigation were suitable for each type of priming. The most effective treatment was soaking soybean seed in $\mathrm{CaCl}_{2}$ solution for longest period (48 hrs.). Therefore it seems that salt used in investigation had a non-toxic effect on seed during priming and promote germination to form a healthy seedling.

\section{Effect of priming type and its duration on protein synthesis}

Mechanisms by seed priming improve germination performance. Seeds complete first two phases of germination during priming process hence primed and dehydrated seeds enter immediately into phase III of imbibition once rehydrated during sowing. The reduction in time of imbibition required RNA, protein synthesis may be occurred and polyribosome formation and consequently on increase in total amount of RNA and protein synthesis.

Protein extracts were analyzed using SDSPAGE, and subjected to electrophoresis to form a protein pattern for each treatment (Fig. 1 \& Table 3), whereas, variation within bands appeared for each treatment meaning that synthesizing proteins affected by type of priming and its duration. Soybeans seeds exposed to hydration for the three periods varied than control, whereas number of protein bands on SDS gel increased from 10 bands separated on control extract to 13,11 and 12 for hydration treatment at periods of 6,12 and 24 hrs., respectively (Fig $1 \&$ Tables 3,4 and 5).

Number of mono, poly-uni and unique bands varied as well as its intensive dye, meaning that amount of formed protein varied within treatments.

Results showed that hydrated seed for longest period (24 hrs.) had a special pattern in darkness and number of bands. Such changes may help seed to perform germination characteristics more uniformly and more rapid.

On the other hand, seeds exposed to soaking in PEG solution for short, medium and long period (12 hrs., 24 hrs. and 48 hrs., respectively) showed variation in separated proteins at SDSPAGE when compared to control (Fig. 1 \& Tables 3, 4 and 5). Additionally protein pattern of each period varied in number of bands and RF of each band. It seems that seeds which soaked for longest period in PEG solution formed more proteins separated at more bands. This finding may be attributed with the enhanced germination obtained for the same treatment (soaking PEG for $48 \mathrm{hrs}$.).

Longest duration formed more protein bands detected on SDS gel. Exposing seeds to salt solution of $\mathrm{CaCl}_{2}$ for longest period (48 hrs.) gave less bands of separated protein which formed on SDS gel. Results concluded that salts may affect protein synthesis, since soaking soybean seeds in $\mathrm{CaCl}_{2}$ enhanced germination, seedling growth and protein synthesis. 
Table 1. Effect of priming type, application period and their interaction on soybean seed germination characters during (2016/2017 seasons)

\begin{tabular}{|c|c|c|c|c|c|}
\hline \multirow[b]{2}{*}{ Treatment } & \multicolumn{5}{|c|}{ Germination characteristics } \\
\hline & $\begin{array}{c}\text { Germination } \\
\% \\
\text { G\% } \\
\end{array}$ & $\begin{array}{c}\text { Germination } \\
\text { rate } \\
\text { GR }\end{array}$ & $\begin{array}{c}\text { First day of } \\
\text { germination(d) } \\
\text { FDG }\end{array}$ & $\begin{array}{c}\text { Last day of } \\
\text { germination(d) } \\
\text { LDG }\end{array}$ & $\begin{array}{c}\text { Germination } \\
\operatorname{period}(d) \\
\text { GP }\end{array}$ \\
\hline Control & 40 & 0.46 & 7.0 & 12.0 & 5.0 \\
\hline $\begin{array}{l}\text { Hydro-priming } \\
\text { Short period } \\
\text { Medium period }^{\star *} \\
\text { Long period }^{\star \star *}\end{array}$ & $\begin{array}{l}52.0 \\
52.0 \\
60.0\end{array}$ & $\begin{array}{l}0.52 \\
0.41 \\
0.60\end{array}$ & $\begin{array}{l}8.0 \\
8.0 \\
8.0\end{array}$ & $\begin{array}{l}12.0 \\
12.0 \\
11.0\end{array}$ & $\begin{array}{l}4.0 \\
4.0 \\
3.0\end{array}$ \\
\hline $\begin{array}{l}\text { Osmo- priming } \\
\text { Short period } \\
\text { Medium period } \\
\text { Long period }\end{array}$ & $\begin{array}{l}76.0 \\
78.0 \\
80.0\end{array}$ & $\begin{array}{l}0.53 \\
0.57 \\
0.59\end{array}$ & $\begin{array}{l}8.0 \\
7.0 \\
8.0\end{array}$ & $\begin{array}{l}12.0 \\
12.0 \\
12.0\end{array}$ & $\begin{array}{l}4.0 \\
5.0 \\
4.0\end{array}$ \\
\hline $\begin{array}{l}\text { Salt- priming } \\
\text { Short period } \\
\text { Medium period } \\
\text { Long period }\end{array}$ & $\begin{array}{l}80.0 \\
86.0 \\
96.0\end{array}$ & $\begin{array}{l}0.58 \\
0.63 \\
0.64\end{array}$ & $\begin{array}{l}7.0 \\
7.0 \\
7.0 \\
\end{array}$ & $\begin{array}{l}12.0 \\
12.0 \\
12.0 \\
\end{array}$ & $\begin{array}{l}5.0 \\
5.0 \\
5.0\end{array}$ \\
\hline L.S.D 5\% & 4.28 & 0.06 & NS & NS & NS \\
\hline $\begin{array}{l}\text { Control } \\
\text { Hydro-priming } \\
\text { Osmo- priming } \\
\text { Salt- priming }\end{array}$ & $\begin{array}{c}40 \\
51.0 \\
68.5 \\
75.5 \\
\end{array}$ & $\begin{array}{l}0.46 \\
0.50 \\
0.50 \\
0.60\end{array}$ & $\begin{array}{l}7.0 \\
7.8 \\
7.5 \\
7.0 \\
\end{array}$ & $\begin{array}{l}12.0 \\
11.8 \\
12.0 \\
12.0 \\
\end{array}$ & $\begin{array}{l}5.0 \\
4.0 \\
4.5 \\
5.0 \\
\end{array}$ \\
\hline L.S.D $5 \%$ & 2.14 & 0.03 & 0.04 & NS & 0.37 \\
\hline $\begin{array}{l}\text { Short period } \\
\text { Medium period } \\
\text { Long period }\end{array}$ & $\begin{array}{l}69.3 \\
72.0 \\
78.7\end{array}$ & $\begin{array}{l}0.50 \\
0.50 \\
0.60\end{array}$ & $\begin{array}{l}7.7 \\
7.3 \\
7.7 \\
\end{array}$ & $\begin{array}{l}12.0 \\
12.0 \\
11.7 \\
\end{array}$ & $\begin{array}{l}4.3 \\
4.7 \\
4.0\end{array}$ \\
\hline L.S.D $5 \%$ & 2.47 & 0.03 & NS & NS & NS \\
\hline
\end{tabular}

*Short period of priming were 6, 12 and 12 hrs. for hydro-priming, osmo-priming and salt-priming respectively. ${ }^{*}$ Medium period of priming were 12, 24 and 24 for hydro-priming, osmo-priming and salt-priming respectively. ** Long period of priming were 24,48 and 48 for hydro-priming, osmo-priming and salt priming respectively. 
Table 2. Effect of type of priming, application period and their interaction on soybean seedling characters during $(2016 / 2017$ season)

\begin{tabular}{|c|c|c|c|c|}
\hline \multirow[b]{2}{*}{ Treatment } & \multicolumn{4}{|c|}{ Seedling characteristics } \\
\hline & $\begin{array}{l}\text { Shoot length } \\
\text { (cm) }\end{array}$ & $\begin{array}{l}\text { Root length } \\
\text { (cm) }\end{array}$ & $\begin{array}{l}\text { Seedling length } \\
\text { (cm) }\end{array}$ & $\begin{array}{c}\text { Seedling dry weight } \\
\text { (g.) }\end{array}$ \\
\hline Control & 2.7 & 3.5 & 6.2 & 0.03 \\
\hline $\begin{array}{l}\text { Hydropriming } \\
\text { Short period* }^{*} \\
\text { Medium period }^{* *} \\
\text { Long period* }^{*}\end{array}$ & $\begin{array}{l}3.2 \\
2.9 \\
3.4\end{array}$ & $\begin{array}{l}4.0 \\
3.8 \\
4.1\end{array}$ & $\begin{array}{l}7.2 \\
6.7 \\
7.5\end{array}$ & $\begin{array}{l}0.04 \\
0.03 \\
0.04\end{array}$ \\
\hline $\begin{array}{l}\text { Osmo-priming } \\
\text { Short period } \\
\text { Medium period } \\
\text { Long period }\end{array}$ & $\begin{array}{l}3.4 \\
3.2 \\
3.5\end{array}$ & $\begin{array}{l}3.9 \\
3.9 \\
4.1\end{array}$ & $\begin{array}{l}7.3 \\
7.1 \\
7.6\end{array}$ & $\begin{array}{l}0.04 \\
0.03 \\
0.04\end{array}$ \\
\hline $\begin{array}{l}\text { Salt-priming } \\
\text { Short period } \\
\text { Medium period } \\
\text { Long period }\end{array}$ & $\begin{array}{l}3.4 \\
3.7 \\
4.0\end{array}$ & $\begin{array}{l}4.3 \\
4.4 \\
5.0\end{array}$ & $\begin{array}{l}7.7 \\
8.1 \\
9.0\end{array}$ & $\begin{array}{l}0.05 \\
0.05 \\
0.06\end{array}$ \\
\hline L.S.D $\quad 5 \%$ & 0.17 & 0.26 & 0.37 & 0.008 \\
\hline $\begin{array}{l}\text { Control } \\
\text { Hydro-priming } \\
\text { Osmo-priming } \\
\text { Salt-priming }\end{array}$ & $\begin{array}{l}2.7 \\
3.1 \\
3.2 \\
3.5\end{array}$ & $\begin{array}{l}3.5 \\
3.9 \\
3.9 \\
4.3\end{array}$ & $\begin{array}{l}6.2 \\
6.9 \\
7.1 \\
7.8\end{array}$ & $\begin{array}{l}0.03 \\
0.04 \\
0.04 \\
0.05\end{array}$ \\
\hline L.S.D $5 \%$ & 0.08 & 0.13 & 0.19 & 0.005 \\
\hline $\begin{array}{l}\text { Short period } \\
\text { Medium period } \\
\text { Long period }\end{array}$ & $\begin{array}{l}3.3 \\
3.3 \\
3.6\end{array}$ & $\begin{array}{l}4.1 \\
4.0 \\
4.4\end{array}$ & $\begin{array}{l}7.4 \\
7.3 \\
8.0\end{array}$ & $\begin{array}{l}0.04 \\
0.04 \\
0.05\end{array}$ \\
\hline L.S.D $5 \%$ & 0.10 & 0.15 & 0.21 & 0.005 \\
\hline
\end{tabular}

*Short period of priming were 6,12 and 12 hrs for hydro-priming, osmo-priming and salt-priming respectively. ${ }^{* *}$ Medium period of priming were 12, 24 and 24 for hydro-priming, osmo-priming and salt-priming respectively.

${ }^{* \star}$ Long period of priming were 24,48 and 48 for hydro-priming, osmo-priming and salt- priming respectively. 


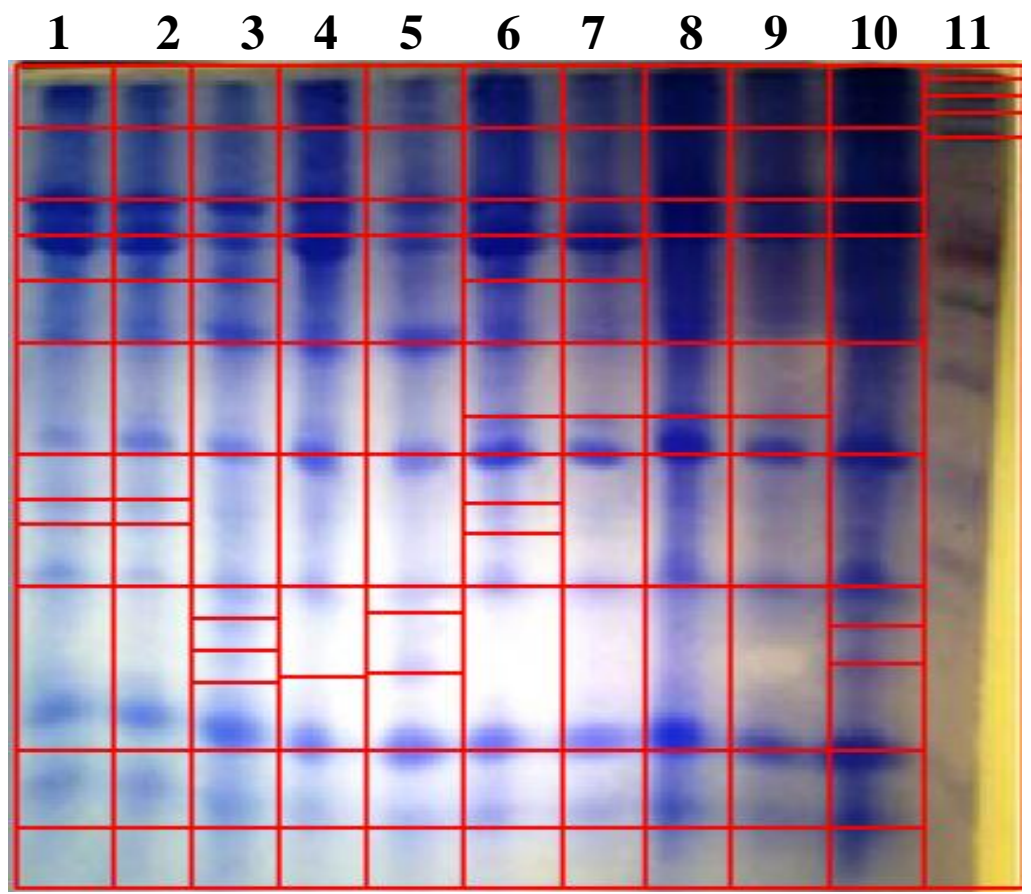

Fig. 1. Soybean seed proteins pattern separated using SDS electrophoresis subjected to different types of priming for different periods

Lane 1: Hydro-priming for $6 \mathrm{hrs;}$ Lane 2: Hydro-priming for $12 \mathrm{hrs;}$ Lane 3: Hydropriming for $24 \mathrm{hrs;} \mathrm{Lane} \mathrm{4:} \mathrm{Osmo-priming} \mathrm{for} 12 \mathrm{hrs;} \mathrm{Lane} \mathrm{5:} \mathrm{Osmo-priming} \mathrm{for} 24 \mathrm{hrs;} \mathrm{Lane}$ 6: Osmo-priming for $48 \mathrm{hrs;} \mathrm{Lane} \mathrm{7:} \mathrm{Salt-priming} \mathrm{for} 12 \mathrm{hrs;} \mathrm{Lane} \mathrm{8:} \mathrm{Salt-priming} \mathrm{for} 24 \mathrm{hrs;}$ Lane 9: Salt-priming for $48 \mathrm{hrs;}$ Lane 10: Untreated seed (control) and Lane 11: Molecular weigh marker.

Table 3. Bands and its (RF) of soybean seed proteins separated using SDS electrophoresis subjected to different types of priming for different priods

\begin{tabular}{|c|c|c|c|c|c|c|c|c|c|c|c|}
\hline \multirow{2}{*}{ RF } & \multicolumn{4}{|c|}{ Hydro-priming } & \multicolumn{2}{c|}{ Osmo-priming } & \multicolumn{3}{c|}{ Salt-priming } & \multirow{2}{*}{ Control } & Marker \\
\cline { 2 - 10 } & $\mathbf{6}$ & $\mathbf{1 2}$ & $\mathbf{2 4}$ & $\mathbf{1 2}$ & $\mathbf{2 4}$ & $\mathbf{4 8}$ & $\mathbf{1 2}$ & $\mathbf{2 4}$ & $\mathbf{4 8}$ & Cours \\
& Hours & Hours & Hours & Hours & Hours & Hours & Hours & Hours & Hours & & \\
\hline Band1 & 0.076 & 0.076 & 0.076 & 0.076 & 0.076 & 0.076 & 0.076 & 0.076 & 0.076 & 0.076 & 0.016 \\
Band2 & 0.163 & 0.163 & 0.163 & 0.163 & 0.163 & 0.163 & 0.163 & 0.163 & 0.163 & 0.163 & 0.037 \\
Band3 & 0.206 & 0.206 & 0.206 & 0.206 & 0.206 & 0.206 & 0.206 & 0.206 & 0.206 & 0.206 & 0.057 \\
Band4 & 0.262 & 0.262 & 0.262 & 0.337 & 0.337 & 0.262 & 0.262 & 0.337 & 0.337 & 0.337 & 0.087 \\
Band5 & 0.337 & 0.337 & 0.337 & 0.472 & 0.472 & 0.337 & 0.337 & 0.427 & 0.427 & 0.472 & ---- \\
Band6 & 0.472 & 0.472 & 0.472 & 0.633 & 0.633 & 0.427 & 0.427 & 0.472 & 0.472 & 0.633 & ----- \\
Band7 & 0.528 & 0.528 & 0.633 & 0.743 & 0.665 & 0.472 & 0.472 & 0.633 & 0.633 & 0.681 & ---- \\
Band8 & 0.557 & 0.557 & 0.672 & 0.833 & 0.739 & 0.532 & 0.633 & 0.833 & 0.833 & 0.727 & ---- \\
Band9 & 0.633 & 0.633 & 0.711 & 0.927 & 0.833 & 0.569 & 0.833 & 0.927 & 0.927 & 0.833 & ----- \\
Band10 & 0.833 & 0.833 & 0.750 & 0.000 & 0.927 & 0.633 & 0.927 & 0.000 & 0.000 & 0.927 & ---- \\
Band11 & 0.927 & 0.927 & 0.833 & 0.000 & 0.000 & 0.833 & 0.000 & 0.000 & 0.000 & 0.000 & ---- \\
Band12 & 0.000 & 0.000 & 0.927 & 0.000 & 0.000 & 0.927 & 0.000 & 0.000 & 0.000 & 0.000 & ----- \\
\hline
\end{tabular}



types of seed priming

Table 4. Molecular weight (MW) of soybean seed proteins separated using SDS electrophoresis subjected to different types of priming for different periods

\begin{tabular}{|l|c|c|c|c|c|c|c|c|c|c|c|}
\hline \multirow{2}{*}{ MW-bp } & \multicolumn{3}{|c|}{ Hydro-priming } & \multicolumn{3}{c|}{ Osmo-priming } & \multicolumn{3}{c|}{ Salt-priming } & \multirow{2}{*}{ Control } & Marker \\
\cline { 2 - 10 } & $\begin{array}{c}\mathbf{6} \\
\text { Hours }\end{array}$ & $\begin{array}{c}\mathbf{1 2} \\
\text { Hours }\end{array}$ & $\begin{array}{c}\mathbf{2 4} \\
\text { Hours }\end{array}$ & $\begin{array}{c}\mathbf{1 2} \\
\text { Hours }\end{array}$ & $\begin{array}{c}\mathbf{2 4} \\
\text { Hours }\end{array}$ & $\begin{array}{c}\mathbf{4 8} \\
\text { Hours }\end{array}$ & $\begin{array}{c}\mathbf{1 2} \\
\text { Hours }\end{array}$ & $\begin{array}{c}\mathbf{2 4} \\
\text { Hours }\end{array}$ & $\begin{array}{c}\mathbf{4 8} \\
\text { Hours }\end{array}$ & & \\
\hline Band1 & 140.125 & 140.125 & 140.125 & 140.125 & 140.125 & 140.125 & 140.125 & 140.125 & 140.125 & 140.125 & 310.452 \\
Band2 & 44.168 & 44.168 & 44.168 & 44.168 & 44.168 & 44.168 & 44.168 & 44.168 & 44.168 & 44.168 & 236.063 \\
Band3 & 24.963 & 24.963 & 24.963 & 24.963 & 24.963 & 24.963 & 24.963 & 24.963 & 24.963 & 24.963 & 179.499 \\
Band4 & 11.873 & 11.873 & 11.873 & 4.388 & 4.388 & 11.873 & 11.873 & 4.388 & 4.388 & 4.388 & 120.843 \\
Band5 & 4.388 & 4.388 & 4.388 & 0.732 & 0.732 & 4.388 & 4.388 & 1.329 & 1.329 & 0.732 & ---- \\
Band6 & 0.732 & 0.732 & 0.732 & 0.086 & 0.086 & 1.329 & 1.329 & 0.732 & 0.732 & 0.086 & ---- \\
Band7 & 0.348 & 0.348 & 0.086 & 0.020 & 0.056 & 0.732 & 0.732 & 0.086 & 0.086 & 0.046 & ---- \\
Band8 & 0.237 & 0.237 & 0.051 & 0.006 & 0.021 & 0.330 & 0.086 & 0.006 & 0.006 & 0.025 & ---- \\
Band9 & 0.086 & 0.086 & 0.031 & 0.002 & 0.006 & 0.202 & 0.006 & 0.002 & 0.002 & 0.006 & ---- \\
Band10 & 0.006 & 0.006 & 0.018 & 0.000 & 0.002 & 0.086 & 0.002 & 0.000 & 0.000 & 0.002 & ---- \\
Band11 & 0.002 & 0.002 & 0.006 & 0.000 & 0.000 & 0.006 & 0.000 & 0.000 & 0.000 & 0.000 & ---- \\
Band12 & 0.000 & 0.000 & 0.002 & 0.000 & 0.000 & 0.002 & 0.000 & 0.000 & 0.000 & 0.000 & ----- \\
\hline
\end{tabular}

Table 5. Polymorphism data of soybean seed proteins separated using SDS electrophoresis subjected to different types of priming for different periods

Polymorphism Data

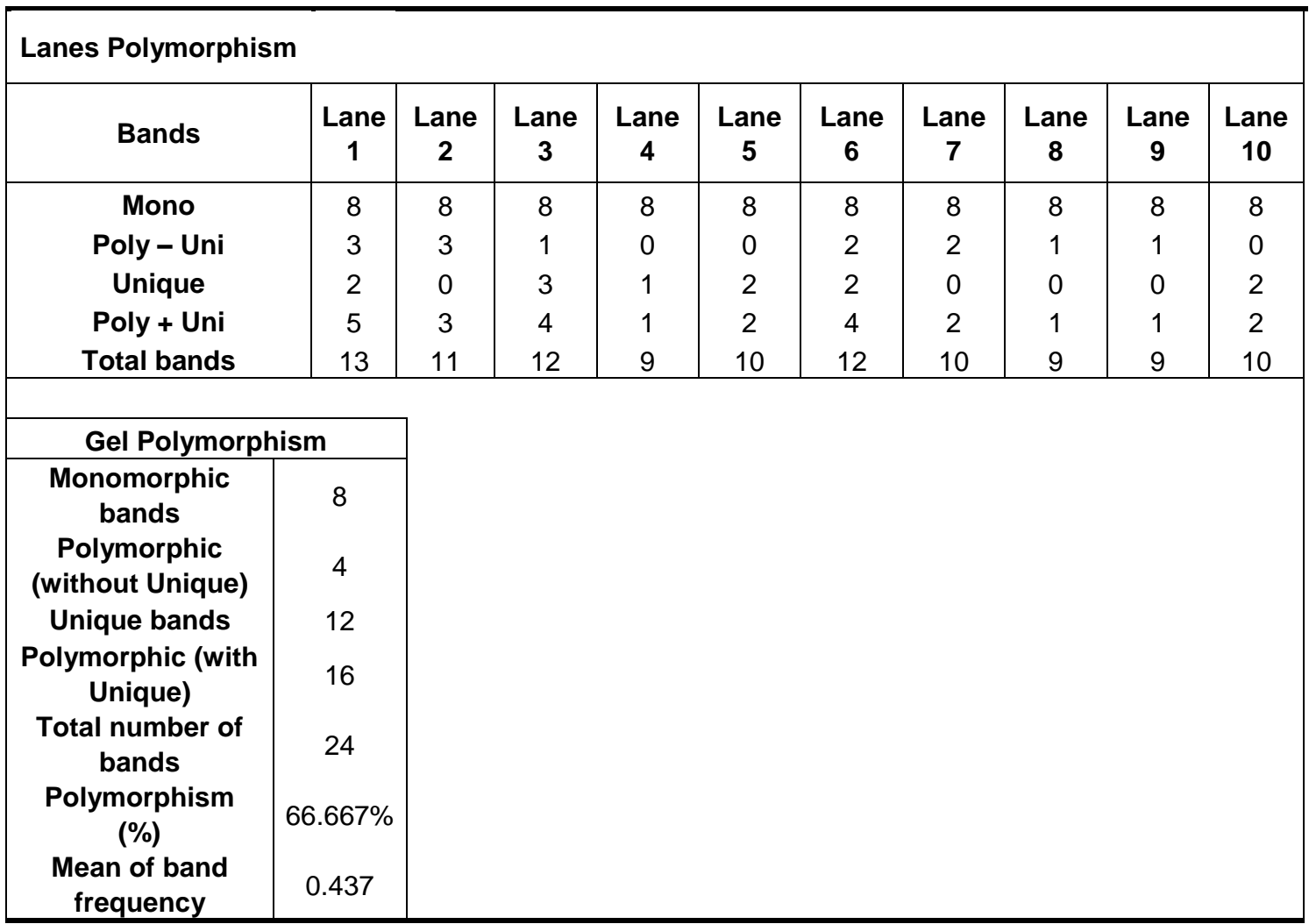




\section{Effect of type of priming and application pe- riod on enzymes activity}

\subsection{Peroxidase activity}

Peroxidase is considered more important enzyme in seed physiological response to priming. Peroxidases are enzymes that typically catalyze the optical substrate in hydrogen peroxide, but others are more active with organic hydro peroxides such as lipid peroxides. Its function breaks down hydrogen peroxide $\left(\mathrm{H}_{2} \mathrm{O}_{2}\right)$, which is the toxin produced as a byproduct of using oxygen for respiration. Staining gel for peroxidase activity showed variation in enzyme activity, whereas, the priming treatments at all studied application periods showed an increasing in peroxidase activity as compared to control (untreated seeds). It was remarkably noticed that longest period of expose (lane 3 ) showed the highest peroxidase activity as compare to control and short or medium exposing periods (6 and $12 \mathrm{hrs}$ ). Also it was noticed that there were a unique diffuse band at the end of the lane (Fig. 2). These bands were less intensive in staining color, their activities was less than those extracted from hydro-primed seeds for short and medium periods (6 and $12 \mathrm{hrs}$ respectively). Results revealed that osmo-priming affected peroxidase enzyme activity causing enhancement in activity more that untreated (control) seed, while exposing period for osmotic substrate of PEG 6000 did not affect activity of peroxidase enzyme remarkably (Fig. 2).

Salt priming showed an interesting long activity band more than other treatments (Fig. 2). Long exposing period for salt prime solution enhanced maximum enzyme activity to level. Such finding revealed that salt priming technique which had the most effect on peroxidase activity especially for the longest exposing period (48 hts).

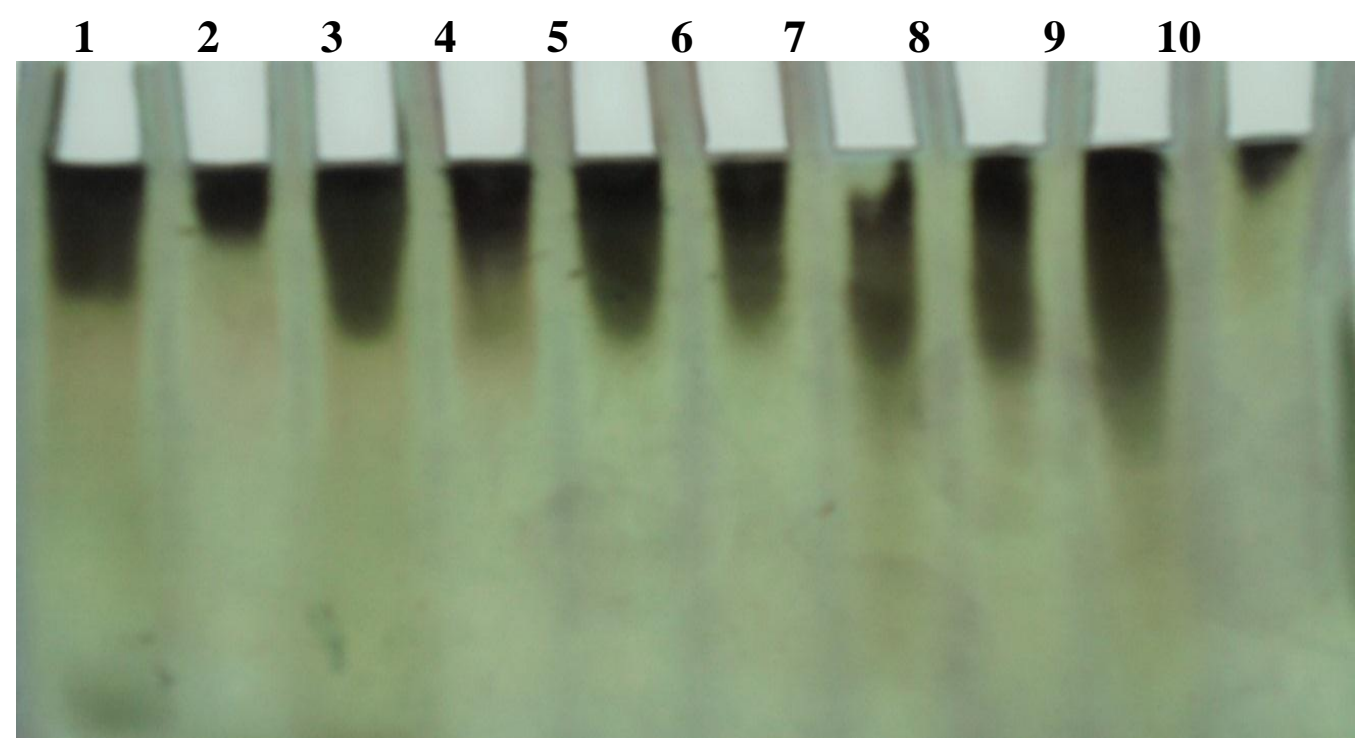

Fig. 2. Identification of peroxidase isozyme in soybean seed extracts as responding to different priming types and different application periods.

Lane 1 : Hydro-priming for $6 \mathrm{hrs;}$ Lane 2: Hydro-priming for $12 \mathrm{hrs;}$ Lane 3: Hydro-priming for $24 \mathrm{hrs}$; Lane 4: Osmo-priming for 12 hrs; Lane 5: Osmo-priming for $24 \mathrm{hrs;} \mathrm{Lane} \mathrm{6:} \mathrm{Osmo-}$ priming for $48 \mathrm{hrs}$; Lane 7: Salt-priming for $12 \mathrm{hrs;} \mathrm{Lane} \mathrm{8:} \mathrm{Salt-priming} \mathrm{for} 24 \mathrm{hrs;} \mathrm{Lane} \mathrm{9:} \mathrm{Salt-}$ priming for $48 \mathrm{hrs;}$ Lane 10: untreated seed ( control) 


\subsection{Esterase activity}

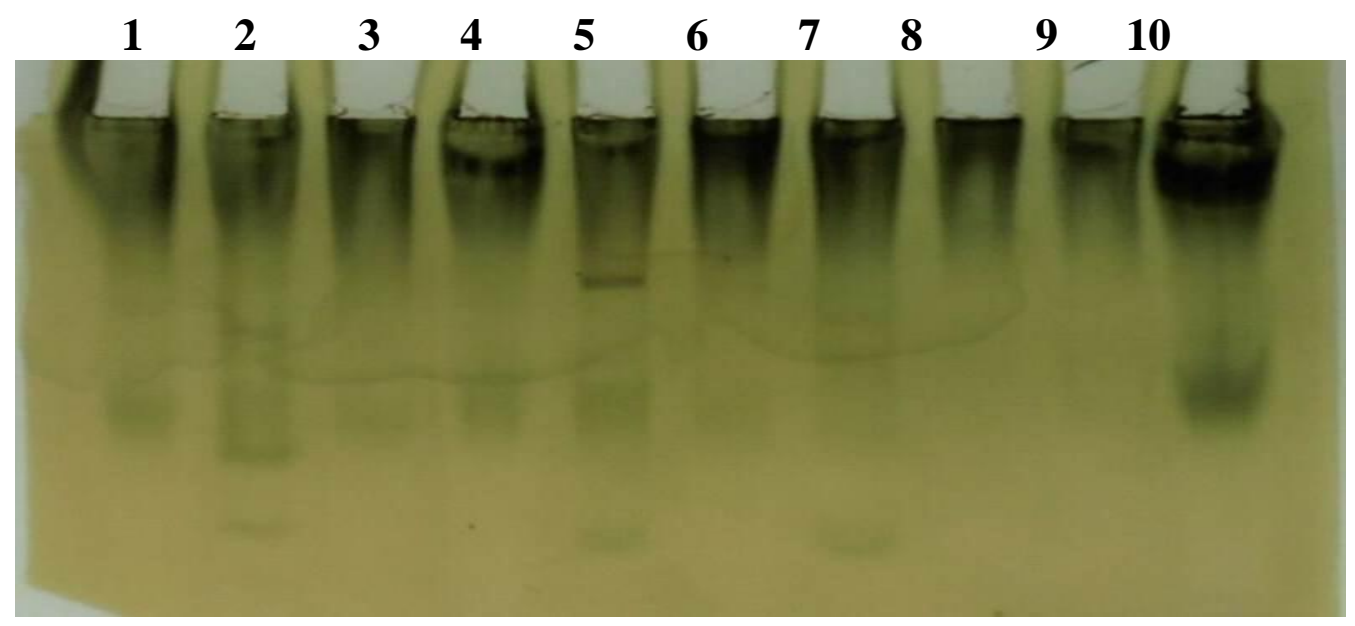

Fig. 3. Identification of esterase isozymes in soybean seed extracts as responding to different priming types and different priming types and different application periods.

Lane 1 : Hydro-priming for 6 hrs ; Lane 2 : Hydro-priming for 12 hrs ; Lane 3 : Hydropriming for $24 \mathrm{hrs}$; Lane 4: Osmo-priming for $12 \mathrm{hrs}$; Lane 5 : Osmo-priming for $24 \mathrm{hrs}$; Lane 6 : Osmo-priming for $48 \mathrm{hrs}$; Lane 7 : Salt priming for $12 \mathrm{hrs} \mathrm{;} \mathrm{Lane} 8$ : Salt priming for 24 hrs ; Lane 9 : Salt priming for 48 hrs; Lane 10 : untreated seed (control).

Esterase is a hydrolase enzyme that splits esterase into acid and an alcohol in a chemical reaction with water called hydrolysis. A wide range of esterase exists that differ in their substrate specificity. The esterase activity bands had two prolonged regions, and bands appeared as a diffuse band with intensive region and the second appeared as a less activity diffuse region that was clearly noticed extracts of untreated seeds (Fig. 3).

The two major bands were diminished by priming treatments. However, variation observed within bands due to type of priming and period was slightly remarkable. It was clear that increasing period of exposing seeds to priming caused reduction esterase activity since intensive band diminished in their darkness however, there was a slight third band appeared for medium application extract. On the other hand, extracts of osmo-priming showed a slight activity especially the second diffuse band. Also a third band appeared as a slight faint bond within extracts of osmo-priming for medium application period, meaning that, a new isozyme was formed.

The most interesting finding in images of esterase activity gel was decreasing of the second diffuse region of esterase activity for all treatment investigated compared to untreated seed (control). These findings suggest more investigation on esterase isozymes activity as affected by priming.

\section{REFERENCES}

Ajouri, A., Haben, A. and Becker, M. 2004. Seed priming enhances germination and seedling growth of barley under conditions of $\mathrm{P}$ and $\mathrm{Zn}$ deficiency. J. of Plant Nutr. and Soil Sci. 167, 630-636.

Chavan, N.G., Bhujbal, G.B. and Manjare, M.R. 2014. Effect of seed priming on field performance and seed yield of soybean (Glycine max (L.) Merill) varieties. The Rioscan, 9(1), 111114.

Hossien, S., Fardin, K.H., Liela, Y. and Saman, S. 2011. Effect of seed osmo-priming on seed germination behavior and vigor of soybean (Glycine max L.). Arpn J. and Biol. Sci. 6(1), 39-42.

ISTA (International Seed Testing Association). 1996. International rules for seed testing. Seed Sci. Technol. 24, 155-202.

Khajeh-Hosseini, M., Powell, A.A. and Bingham, I.J. 2003. The interaction between salinity stress and seed vigor during germination of soybean seeds. Seed Sci. and Tech., 31, 715725.

Koller, W. and Kolattukudy, F. 1982. Mechanism of action of cutinose: Chemical modification of the catalytic tried characteristic for serine hydrolases. Bioch. 21, 3083-3090. 
Mewael, KA., Ravi, H., Koti, R.V. and Biradarpatil, N.K. 2010. Enhancement of seed quality in soybean following priming treatments. Karnataka J. Agric. Sci., 23(5), 787-789.

Mohammadi, G.R. 2009. The effect of seed priming on plant traits of late-spring seeded soybean (Glycine max L.). Am. Eur. J. Agric. Environ. Sci. 5, 322-326.

Muhammad, A.,Tariq Jan, M., Mian, I.A., Khan, S.A., Hollington, P. and Harris, D. 2014 Evaluation the Impact of Osmo-priming Varying With Polyethylene Glycol Concentrations and Durations on Soybean. Inter. J. of Agric. and Biol. 16, 359-364.

Muhammad, A.,Tariq Jan, M., Ullahkhan, N., Khan, A., Khan, M.J. and Munir, N. 2010. Effect of seed priming on growth parameters of soybean. Pak. J. Bot., 42(4), 2803-2812.

Muhammad, A., Tariq Jan, Marwat, K.B. and Khan, M.A. 2008. Seed priming improves emergence and yield of soybean. Pak. J. Bot., 40(3), 1169-1177.

Park, E., Choi, Y.S., Jeong, J.Y. and Lee, S.S. 1999. Effect of priming on germination of Aged soybean seeds. Korean J. Crop Sci. 44(1), 74-77.

Sayed, S.M., Alaei, Y. and Khanghar, A.M. 2014. The effect of water seed pre-treatment on soybean vegetative and reproductive traits. Int. J. of Agric. and Forest. 4(3A), 12-17.

Snedecor, G.W. and Cochran, W.G. 1991. Statistical methods. $7^{\text {th }}$ ed. lowa stat. Univ., Press. lowa, P.E. USA.

Sung, J.M. and Chang, Y.H. 1993. Biochemical activities associated with priming of sweet corn seeds to improve vigor. Seed Sci. Tech. 21, 97-105.

ToesIli, M.E. and Casenave, E.C. 2003. Water content and the effectiveness of hydro and osmotic priming of cotton seeds. Seed Sci. and Technol., 31, 727-735. 


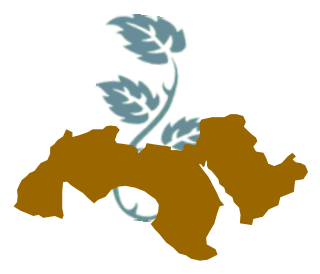

\title{
التغيرات البيولوجية في بذور فول الصويا أثناء تعريضها لعدة أنماط من معاملات \\ استعادة البذور لجودتها
}

[135]

\author{
محمد حسين محمد 1 - أثرف ماهر زكي 1 - ألفت حسن الباجوري 1 - \\ رانيا احمد عبد المقصود يونس 2 \\ 1- قسم المحاصيل - كليه الزراعة - جامعه عين شمس - ص.ب. 68 حدائق شبرا 11241- القاهره - مصر ئر \\ 2- قسم الوراثة - كليه الزراعة - جامعه عين شمس - ص.ب. 68 حدائق شبرا 11241- القاهره - مصر
}

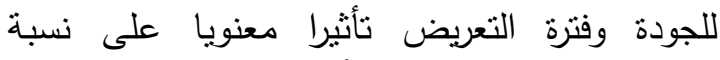

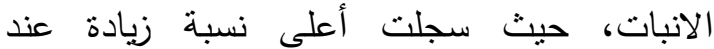
استخدام محلول كلوريد الكالسيوم لأطول فترة (48) فيادة

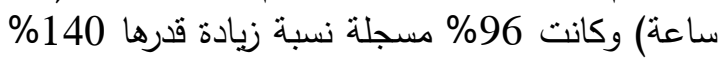

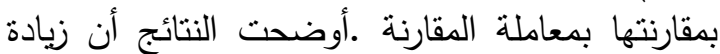

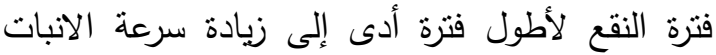

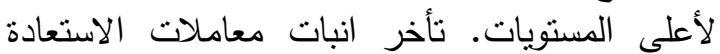
بالترطيب والاستعادة الاسموزية من سبعة أيام لـعاملة

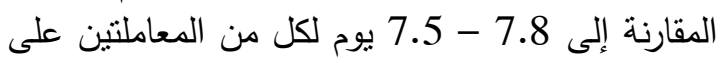
الترتيب. أظهرت كل من معاملة الاستعادة بالترطيب والاستعادة الاسموزية فترات أكبر للإنبات. بوجه عام الإنعادة بالترطاب

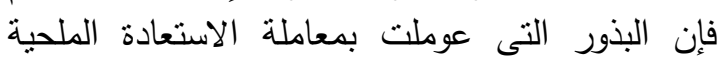

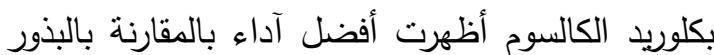

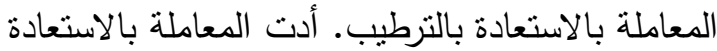

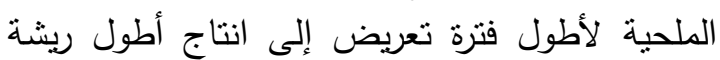
للبادرة. أنتجت البذور المعاملة بالاستعادة الملحية المبارية

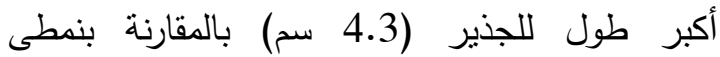

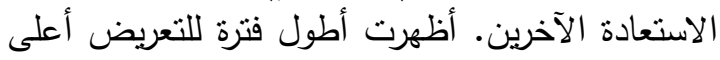

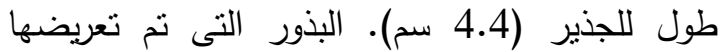

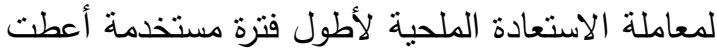

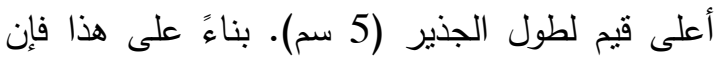
أطوال البادرة قد أظهرت نفس اتجاهات بيانات أطوال الطال

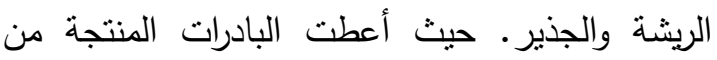
معاملات الاستعادة الملحية أكبر أطوال للبادرة (7.8 سم) بالمقارنة بأنماط الاستعادة الأخرى. أدى تعريض لإدان (لادي
الكلمات الدالة: فول الصويا، معاملة إستعادة البذور

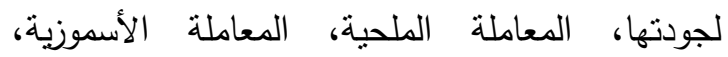
المعاملة بالترطيب، إنبات البذور، النشاط الإنزيمى، بروكسيديز ، إستريز

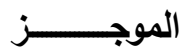

أجريت عدة تجارب معطلية فى معملى بذور

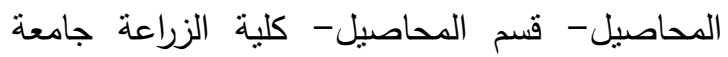
عين شمس ومركز الهندسة الوراثية والبيوتكنولوجى قسم الزئ الوراثة- كلية الزراعة- جامعة عين شمس لتئنة التقدير

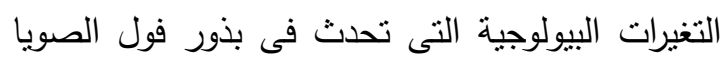

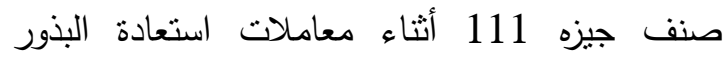
لجودتها، حيث أجريت ثلاثة أنماط (الترطيب- المعاملة

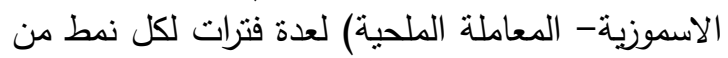

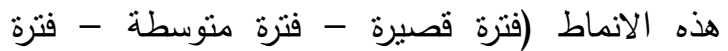

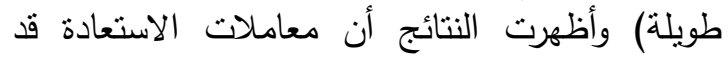

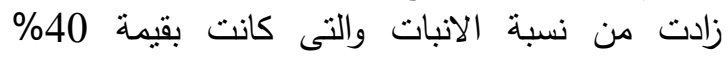
للمقارنة،حيث بلغت نسبة الإنبات 51\%- 68\% -

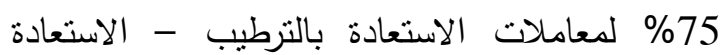

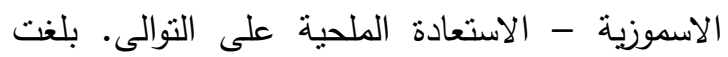
أعلى استجابة لبذور فول الصويا المعاملة بالاستعادة الإنة الملحية، حيث بلغت نسبة الإنبات

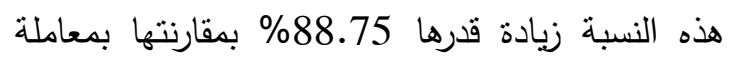
المقارنة. أظهر التفاعل بين معاملة نمط الاستعادة 
حزم البروتينات المفصولة على جيل SDS وذلك عند مقارنتها بمعاملة المقارنة. علاوة على ذلك فلك فإن أنماط

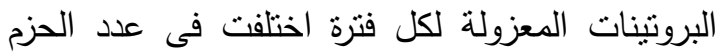
وفى RF لكل حزمة إلا أنه من الواضح النح أن السماح

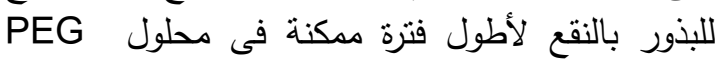

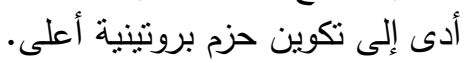

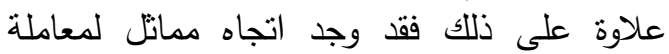

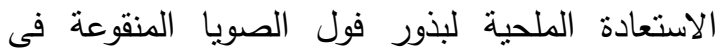

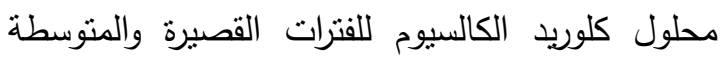
والطويلة (12- 24 - 48 ساعة). بالنظر إلى معاملة

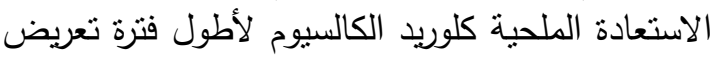

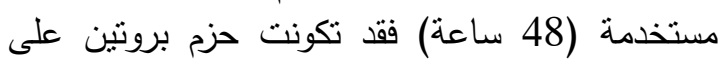
جيل SDS أقل من معاملة المقارنة. أظهرت كل معاملات استعادة الجودة لكل الفترات زيادة واضحة فى نثاط انزيم البيروكسيديز بالمقارنة الفيانة

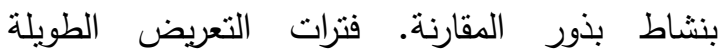

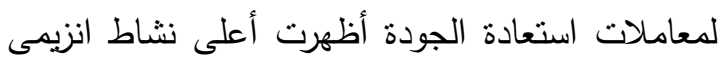

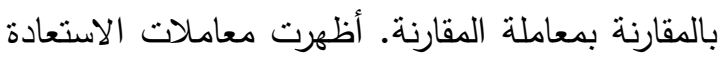
الاسموزية للفترات (القصبرة - المتوسطة - الطفارية الطويلة)

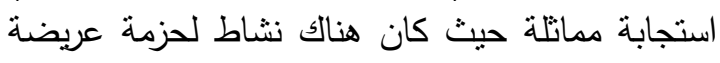

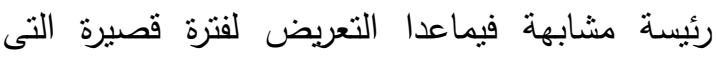

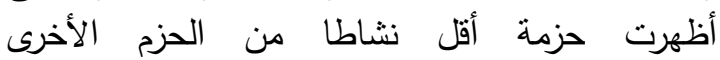

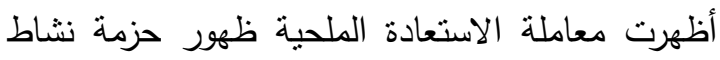

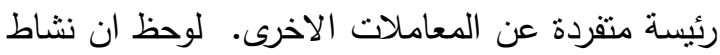

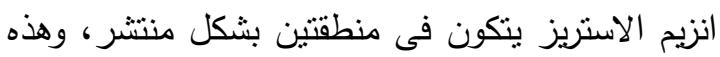

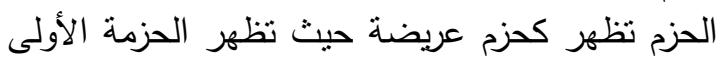

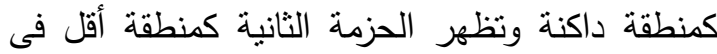
كثافة اللون. الحزمتان المتكونتان لنشاط إنظئ إنزيم الاستريز

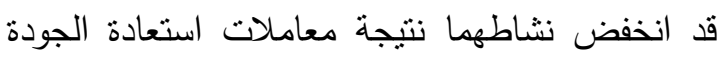
وكانت الاختلافات فى الحزم نتيجة معاملات التهات الاستعادة

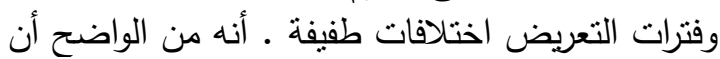

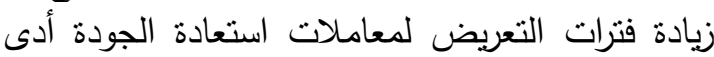

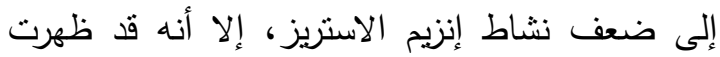

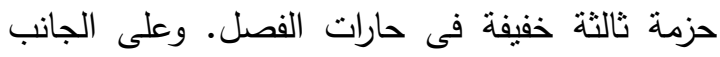
الاخر فإن مستخلص البذه فارلة المعاملة بالاستعادة

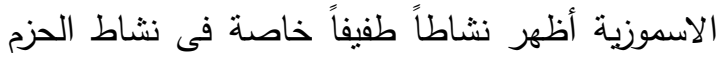

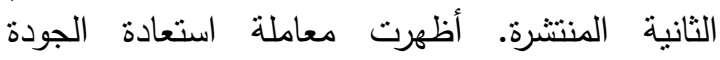

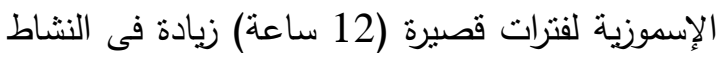
للحزمة الأولى بالمقارنة بالحزمنين الاخرتين للنشاط.
بذور فول الصويا لأطول فترات تعريض لمعاملات

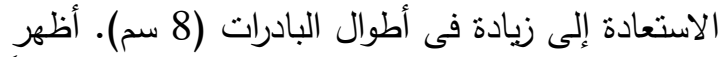

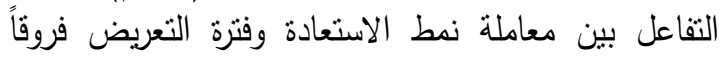
معنوية فى بيانات طول البادرة حيث سجلت أطول البادرات

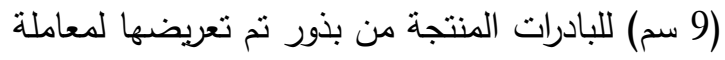
الاستعادة الملحية لأطول فترة مستخدمة (48 ساعة لإنة).

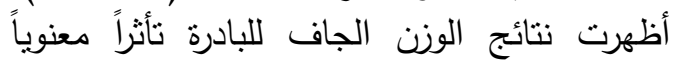

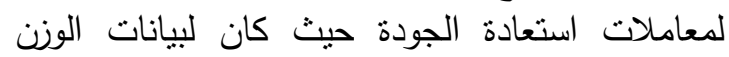

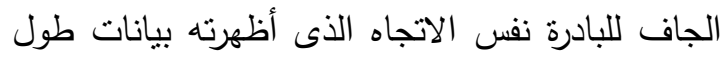

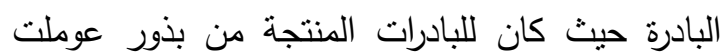

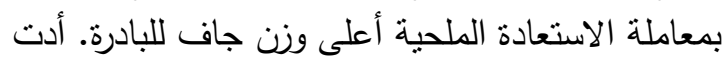

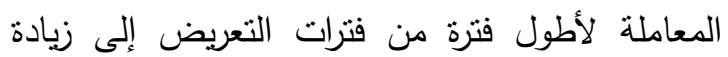

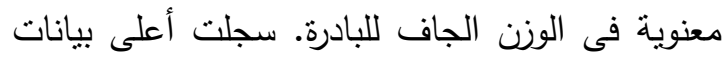

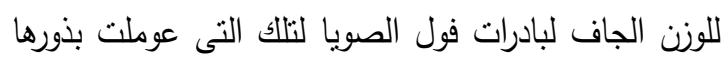

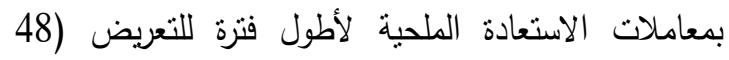
ساعة). يمكن أن نستخلص أن أفضل النض نتائج للانبات

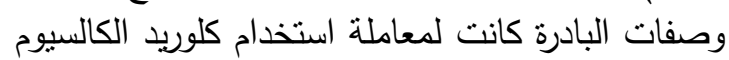
(الاستعادة الملحية) لمدة 48 ساعة ( أطول فترة ).

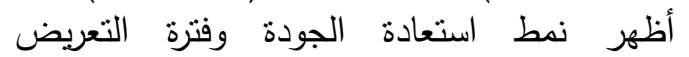

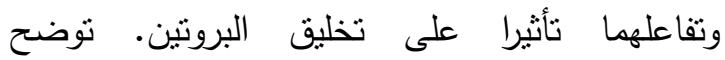

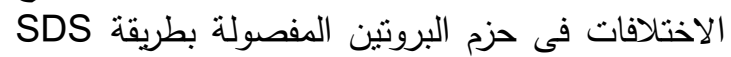
لكل معاملة تخليق بروتينات متأثرة بمعاملات استعادة التئن

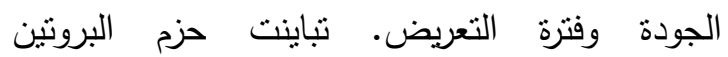
المستخلص من بذور فول الصويا المعاملة باستعادة الئرة

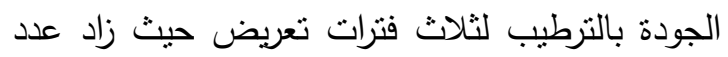

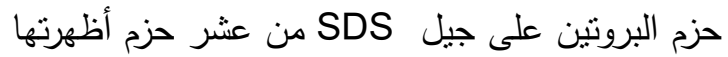

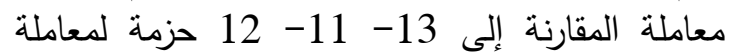

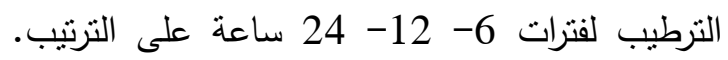
تباينت عدد حزم من نوع (الوحيد- المتعدد- الفريد) كما

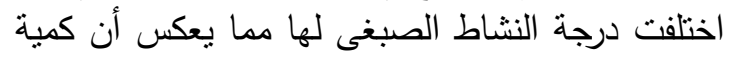

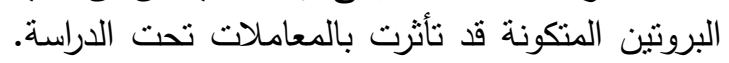

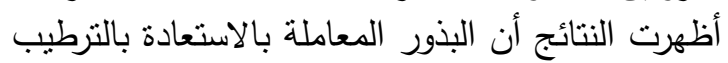

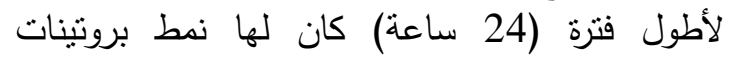

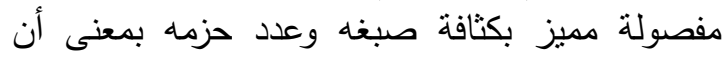

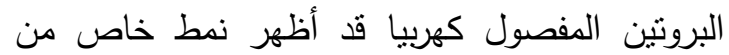

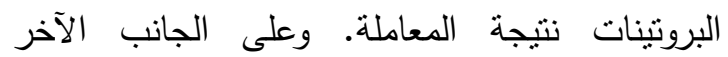

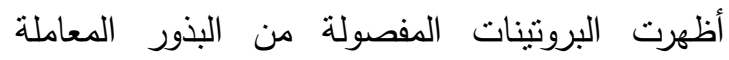
بالاستعادة الأسموزية للفترات القصيرة القيرة والمتوسطة والطويلة (12 - 24 - 48) على التزتيب تباين فى الإنى 
1855

مجلة اتحاد الجامعات العربية

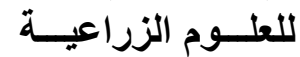

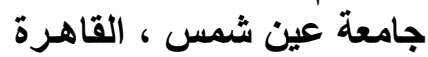

مجلا(26)، عدد (2C)، عدد خاص ، 1841 - 1856، 2018

تحكيم: ا.د رمضان ثابت عبدربه

ا.د خالد طـــه الاففندي 